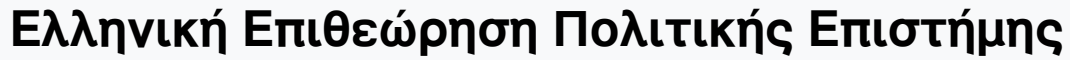

Tó 4.42 (2014)

A

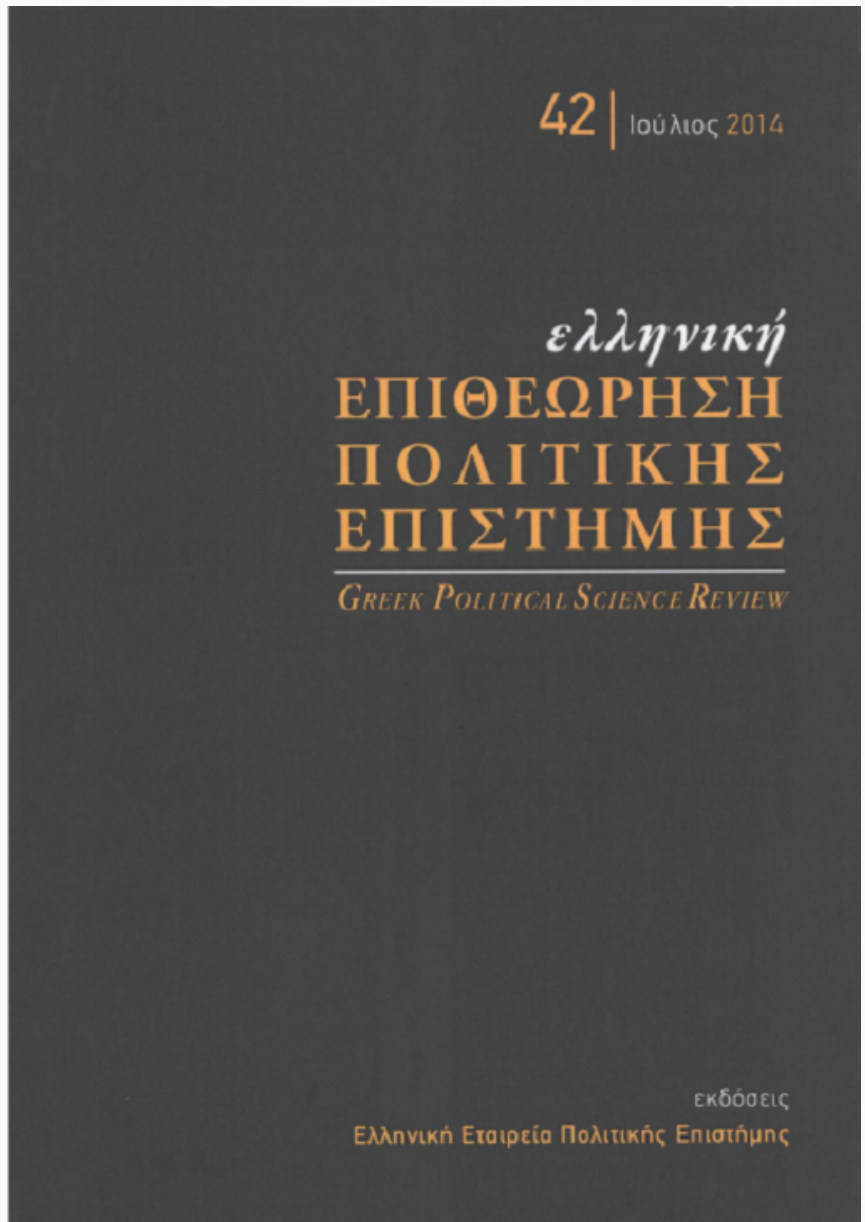

The work of the Council of Europe on the legal regulation of NGOs: A source of inspiration for the Greek legislator

Konstantinos D. Magliveras

doi: $10.12681 /$ hpsa.14572

Copyright ( 2017 , Konstantinos D. Magliveras

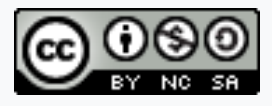

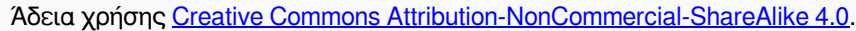

\section{Bıß入ıорачıкń avaчopá:}

Magliveras, K. D. (2017). The work of the Council of Europe on the legal regulation of NGOs: A source of inspiration for

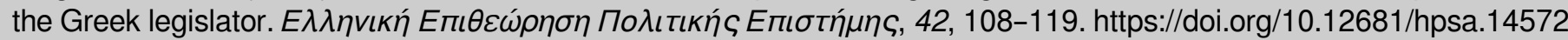




\title{
THE WORK OF THE COUNCIL OF EUROPE ON THE LEGAL REGULATION OF NGOS: A SOURCE OF INSPIRATION FOR THE GREEK LEGISLATOR
}

\author{
Konstantinos D. Magliveras*
}

\begin{abstract}
Notwithstanding that during the last decades NGOs have been very active, their number has ever been on the rise and their influence has increased considerably, the Greek legal order still lacks a legislative framework regulating their establishment and operation. On account of this reality, NGOs have been using the legal personality of other types of entities to perform their goals and mission, for example non-profit companies, associations of natural persons, charitable organizations, etc. Even though these other legal types satisfy to a larger of smaller degree the needs of contemporary NGOs, it is essential to put in place a regulatory framework, which would allow at the same time the troublesome establishment of all types of NGOs and consolidate their legal personality, would permit the State to supervise their creation and thereafter to control their activities (but without interfering in either case) and would devise a system for NGO accountability. The present article argues that the Greek legislator should be inspired by the important and pioneering work which has been carried out by the Council of Europe. While this intergovernmental organisation is far more known for the protection of fundamental freedom (and indeed the freedom to establish NGOs should be viewed as a right protected under the European Human Rights Convention), its work on the regulation of NGOs deserves to be studied in far more detail, principally its 2007 Recommendation on the Legal Status of NGOs in Europe. The latter does serve as a regulatory text addressing at the same time local NGOs but also foreign NGOs active in one or more of the 47 Member States of the Council of Europe.
\end{abstract}

* Konstantinos D. Magliveras is an Associate Professor at the Department of Mediterranean Studies of the University of the Aegean. 


\section{THE QUESTION OF THE NON-REGULATION OF NGOS}

It is a well known fact that in the Greek legal order there exists no set of rules regulating the establishment and the operation of non-governmental organisations (NGOs). In itself, this is not necessarily a bad thing: on many occasions, the lack of regulation permits a larger freedom of movement. However, if an entity or a body is not expressly envisaged in the legal system, its existence and the legality of its activities could easily be challenged. One should hasten to explain that it is not only the Greek legal system, which has no regulative framework for NGOs (either for domestic NGOs, i.e. those established and operating in the Greek territory, or international NGOs (INGOs), i.e. those set up in another state but carrying out their activities in Greece as well). As a matter of fact, most states lack a regulatory framework specifically addressing the life of NGOs: from creation to dissolution. ${ }^{1}$ This has not prevented the phenomenal rise in their number as well as ascending to prominence in the global community. NGOs have managed to sit alongside states and intergovernmental organization and confer during international negotiations.

At the same time, this lack of a specific corpus of legislation distinguishes NGOs from other entities and bodies, which have existed for far longer and are also governed by private law: undertakings, companies, societies, foundations, etc. It is exactly on account of the lack of a regulatory framework that NGOs have had no other option but to use the rules pertaining to these entities and bodies. Arguably, they have done so for three principal reasons. The first is to legitimize their operation. The second is to make possible their participation in the political sphere, in the economic sphere, and in the social affairs sphere. The third is to be allowed to operate as separate legal persons, i.e. as creatures having their own legal personality, separate from the legal personality of their members.

1. The following states have a regulatory framework dealing with NGOs: Afghanistan, Russia, Azerbaijan, Bulgaria, Ukraine, Democratic Republic of Congo, Egypt, Armenia, Kazakhstan, Bosnia-Herzegovina, Finland, Sweden, France, Canada, and Norway. The fact that countries such as Afghanistan have adopted relevant legislation should be attributed to the fact that these states are recipients of large amounts of aid, which is channelled mostly through NGOs, and donors, worried for the fate of their funds, demand that NGOs in recipient states will be adequately regulated. 
II. NGOS CAN BE SET UP EASILY BUT A REGULATORY

FRAMEWORK IS NECESSARY. THE FREEDOM OF ASSOCIATION

AS A PROTECTED HUMAN RIGHT

It should be noted that NGOs, which take the form of an alliance of natural persons aiming at a specific goal, are not required to have a legal mantle. For example, any group of people congregated in a room may, without following any procedures, decide to create a NGO having any objective, provided that is lawful and condoned by the domestic legal system. Thereafter, this group of people will not meet as individuals but as members of a specific entity (namely the NGO which they founded), will be able to deliberate on the basis of any rules which they themselves will adopt, may discuss the implementation and the promotion of the specific objectives to which they will agree, may recruit new members, and so on. To that extend, this NGO will remain, so to speak, a private entity and will not enter the public domain.

However, if the members of this NGO were to decide collectively to externalize its action and activities, in other words if they wish to come into contact publicly with other non-state actors, to become directly involved in societal affairs, to seek funding (either state funding or contributions from the private sector), etc., the NGO must be transposed into an institutionalized alliance of individuals. Practically, this means that the NGO will have to acquire a legal foundation, a juridical basis. Moreover, it will have to subscribe to and abide by the each time applicable rules and procedures, which are laid down in the legal system of the state where it will carry out its objectives.

Invariably, these rules and procedures will have a twofold purpose. The first will be to allow the state to supervise and control NGOs, in particular as regards their aims and activities. This is in line with the fact that, directly or indirectly, states control all private law entities and bodies which are active in their territory. The second will be to ensure that the NGOs and their members will not be harassed by state organs or will not be prevented from exercising their legitimate aims and objectives and that they will not be dissolved arbitrarily by any state authority. As regards dissolution, it may only be taken as a drastic measure of last resort in specific instances which justify it and always in the context of what 
is acceptable in a state subscribing to the rule of law, protecting human rights, and upholding fundamental freedoms. ${ }^{2}$

It should be emphasized that natural persons have a legally protected right to establish together with other individuals bodies and entities, which take any legitimate form (including the form of NGOs), and to pursue their collective interests through them. To put it otherwise, states are under an obligation to tolerate the establishment of NGOs, provided that the applicable rules and procedures have been duly observed. This obligation flows from international human rights law, since it is a fundamental freedom of individuals to organize and pursue their common aspirations through such vehicles. More specifically, this obligation derives from the right of association, a freedom which is laid down in Article 12 of the Greek Constitution ${ }^{3}$ and envisaged in all international and regional treaties for the protection of human rights. Suffice to mention Article 22(1) of the International Covenant on Civil and Political Rights (1966), Article 11 of the European Convention on Human Rights (1950) and Article 12 of the Charter of Fundamental Freedoms of the European Union (2010). ${ }^{4}$ In short, the right of the freedom of association is nowadays accepted (though not necessarily guaranteed and protected) by the vast majority of states in the global community.

2. These instances have to do with the protection of a state's vital interests and are usually manifested in the following triptych: national (public) security, public order (ordre public), and public health.

3. Article 12 of the Constitution stipulates that Greek citizens have the right to establish associations and not for profit foundations by fulfilling the conditions laid down in the legislation; these conditions may not make their establishment dependable on any prior state permission. The content of Article 12 leads to the conclusion that the right of association is not prima faciae enjoyed by aliens. However, it could be argued that the citizens of other Member States of the European Union should also be entitled to it. Whether they should be entitled to it as a separate, self-standing, obligation of the Greek state or whether it can only be exercised on the basis of reciprocity is a legal issue (cf. Article 28(3) of the Constitution), which goes beyond the ambit of this article.

4. The provision in the EU Charter is of particular interest: it moves away the content of the right of association from the freedom to form trade unions, with which it was traditionally linked up in the former two treaties, to cover the freedom to establish, inter alia, associations dealing with civic matters, which could be construed as a reference to the right to set up NGOs. 


\section{A MODERN REGULATORY FRAMEWORK FOR NGOS \\ IS IMPERATIVE. THE ROLE OF THE COUNCIL OF EUROPE. THE NOTION OF MULTINATIONAL NGOS}

The above considerations lead to the conclusion that, while NGOs have been a reality for many decades now in most countries of the world and their creation and operation should be respected and protected, there is still no specific set of rules to regulate them. And such a set of rules should exist in domestic legal orders. As has been noted, there should be a distinction between domestic NGOs and international NGOs. While for the regulation of the latter there have been some initiatives over the years (the majority of states has not shown any interest in them), the discussion in this article concentrates on the regulation of domestic NGOs and, in particular, their regulation in the Greek legal system. Thus, there is a clear need to devise a modern regulatory framework, which will address the special nature of NGOs, will develop favourable conditions for their establishment and the implementation of their objectives but will also create procedures for their supervision and accountability. ${ }^{5}$

In bringing about this task, it is submitted that the Greek legislator ought to be inspired by and make best use of the relevant documents and instruments, which have been adopted by the Council of Europe. The Strasbourg Organisation, as is also known, has to show a very innovative and multifarious work in the regulation of NGOs, more so than any other intergovernmental organisation, including the United Nations. It should be explained that the Council of Europe does not aim at forcing or obliging its Member States to take on the rules and the norms contained in its various instruments (be it treaties, conventions, recommendations, decisions, etc.). On the contrary, its goal is to assist the Member States in formulating the best possible legislation in specific areas, especially areas with an international dimension that need to be regulated in a multilateral fashion.

The first relevant Council of Europe instrument was concluded 28 years ago: the European Convention on the Recognition of the Legal Per-

5. Cf. Conference of the INGOs of the Council of Europe, Expert Council on NGO Law, Third Annual Report, Sanctions and Liability in Respect of NGOs, OING Conf/Exp (2011) 1, January 2011, available at http://www.coe.int/t/ngo/source/expert_council_ngo_law_report_2010_en.pdf. 
sonality of International Non-Governmental Organisations was opened for signature in April $1986 . .^{6}$ It constituted the first ever concrete attempt on the international plane to regulate the operation of what it could be called 'multinational NGOs', namely NGOs active in the territory of more than two of its Member States. ${ }^{7}$ The term 'multinational NGOs' is a manifestation of the fact that, for many years now, their activities have been internationalized through the simultaneous operation of NGOs in the territory of several states while the principal seat remains located in the same state. This brings of course to mind the existence of multinational corporations, which operate through subsidiaries in different countries but have a central administration exercising collective control and oversight. Given the current state of NGOs' evolution, the present article suggests the term 'multinational NGOs' to differentiate it from 'international NGOs', a category which, it is submitted, encompasses NGOs that are active in just two countries. Based on this line of argumentation NGOs such as Amnesty International, Human Rights Watch, and Médecins sans Frontiers should be regarded and treated, from a regulatory point of view, as multinational NGOs.

The reason behind the conclusion of the 1986 Convention was the lack of any legally binding multilateral instrument, which would serve the purpose of promoting the activities and the work of NGOs at a transnational level. According to Article 1, in order for an international NGO to come under its ambit and benefit of the favourable regime that it creates, the following four basic conditions have to be met. The first is that it must possess a non-profit-making aim of international utility. The second is that it must have been established by an instrument which is governed by the domestic law of a contracting party (i.e. a Member State of the Council of Europe which has ratified the Convention). The third is that it must carry on its activities in at least two states, one of which must be a Member State of the Council of Europe while the other state/s could

6. European Treaty Series No 124, text available at https://www.coe.int/t/ngo/ Legal_standards_en.asp.

7. For analysis of the Convention, see K. Magliveras, The Transnational Regulation of NGOs: Revisiting the Council of Europe Convention on Recognition of the Legal Personality of International Non-Governmental Organisations, The Jean Monnet Papers on Political Economy 07/2013, available at http://jmonneteuldcs.wordpress.com/jean-monnetpapers. 
very well be outside Europe. The fourth is that its statutory office must be in the territory of a contracting party and its central management and control in the territory of that same party or of another party.

In case all the above conditions are fulfilled, the legal personality and the capacity that an international NGO has acquired in a contracting party shall be recognized without any further procedures in other contracting parties. Indeed, since international NGOs have a right to expect that their personality will be recognized by the competent authorities in all other contracting parties without any procedural obstacles being erected, one could talk about a right akin to automatic recognition. According to the Articles 2 and 4 of the Convention, the only exception to recognition will be if the other contracting party or parties take the view that the requesting NGO, on the one hand, contravenes national security and public safety, or is detrimental to the prevention of disorder or crime, to the protection of health or morals, or to the protection of the rights and freedoms of others and, on the other hand, jeopardizes relations with another state or the maintenance of international peace and security. All these are valid exceptions falling into the ambit of state sovereignty, although it is rather difficult to envisage situations where an international NGO will pose a threat to international peace and security.

As is also the case with other treaties concluded under the auspices of the Council of Europe, the 1986 Convention has been shunned by Member States. It has never had the response that could have reasonably been expected given its subject matter and the lack of any other similar multilateral instruments. In particular, only 11 out of the current 47 Member States have chosen to become contracting parties to it. ${ }^{8}$ It is a welcomed surprise that Greece was one of the first states to ratify the Convention. ${ }^{9}$ Thus international NGOs, which have been set up in any of the other ten contracting parties, have the ability to pursue their activities in the Greek

8. These Member States are (in brackets the dates that the instruments of ratification were deposited with the Secretary General of the Council of Europe): United Kingdom [3 February 1989], Greece [30 June 1989], Belgium [4 September 1990], Switzerland [24 September 1990], Portugal [28 October 1991], Austria [27 April 1992], Slovenia [16 September 1992], France [26 November 1999], the former Yugoslav Republic of Macedonia [13 July 2000], Cyprus [17 March 2004], and The Netherlands [21 February 2007].

9. It was ratified by virtue of Law $1834 / 1989$ of 10 March 1989, FEK 1989 A' 75. 
territory without any cumbersome procedures and without being obliged to establish a separate NGO. Equally, Greek NGOs can take advantage of their right to operate, without any bureaucratic impediments, in the territory of any other contracting party. To that extend, it could be argued that the Convention creates a kind of right to unhindered establishment, which shares characteristics with the right to establishment that companies and undertakings enjoy under European Union law.

In essence, EU law allows undertakings, which have been lawfully set up and operate in one of the Member States, to pursue their commercial activities in as many of the other Members as they like, while consumers are offered a choice between domestic companies and foreign (EU) companies, which operate on an equal footing, and the Member States are prohibited from discriminating in favour of national companies. Even though there is no recorded state practice as regards the implementation of the 1986 Convention and there are no publicly known cases where international NGOs have invoked it, the content of the Convention is still valid and, in view of the lack of any other similar multilateral instruments, it could play a significant role in assisting NGOs to internationalize their presence. However, it should be noted that Greece does not appear to have either implemented its provisions in domestic law or envisaged procedures for dealing with its practical aspects.

The next initiative by the Council of Europe came in 1998 and took the form of a set of non-binding 'Guidelines on the Functioning of NGOs in Europe'. It was followed in 2002 by another non-binding text, 'Fundamental Principles on the Status of NGOs in Europe'. These two instruments highlighted the involvement of the Council of Europe in recognising and affirming the status and validity of NGOs in the territory of all Member States. Even though the Fundamental Principles did not have any legal force under the Organization's rules and regulations, in 2003 the Committee of Ministers, its highest ranking organ, took note of them with satisfaction and decided that they should be circulated as widely as possible. Soon thereafter work on a follow up instrument commenced, which culminated in the Committee of Ministers adopting in October 2007 the 'Recommendation to Member States on the Legal Status of NGOs in Europe'. ${ }^{10}$ It lays down a set of minimum standards concerning

10. Council of Europe, Committee of Ministers, Recommendation CM/Rec (2007)14, available at https://www.coe.int/t/ngo/Legal_standards_en.asp. 
the creation, organisation, management and legal status of NGOs, whose role in the domestic affairs of Member States is perhaps best illustrated by citing paragraph 76 of the Recommendation:

“76. Governmental and quasi - governmental mechanisms at all levels should ensure the effective participation of NGOs without discrimination in dialogue and consultation on public policy objectives and decisions. Such participation should ensure the free expression of the diversity of people's opinions as to the functioning of society. This participation and co-operation should be facilitated by ensuring appropriate disclosure or access to official information."

The 2007 Recommendation focuses on national legislators, the competent state authorities but the NGOs themselves and aims at suggesting suitable forms for devising legislative instruments, procedure and practices as regards NGOs based on a pluralistic and democratic society upholding the rule of law. In a nutshell, the Recommendation could be seen as a model law for the regulation of NGOs in the Member States. Even if one might disagree with some of its aspects, there is no doubt that it is the first multilateral text covering the main aspects of NGOs, including their establishment, structure, operation, accountability as well as private and public financing. The Recommendation has been drafted in a manner, which, on the one hand, offers the widest possible freedom to NGOs to act and to transact and, on the other hand, restricts as much as possible the ability of state organs to intervene and control them. Moreover, the Recommendation does not discriminate between citizens and aliens (in the sense of giving to the former more rights and privileges compared to the latter) and it is noteworthy that aliens are expressly allowed to be employed by NGOs and are also allowed to participate in their management.

Three other aspects of the 2007 Recommendation are of particular interest because they show that, as a legal creation, NGOs have evolved and are no longer simple associations of individuals. On the contrary, they are complex entities, which for all intents and purposes could be equated to enterprises (other than the motivation to gain profit). The first aspect is that NGOs can be set up not only by natural persons but also by legal persons or by already existing associations of individuals or of legal persons. The second aspect is that NGOs should be left free to carry out 
any kind of lawful economic and commercial activity in order to finance the non profit making activities they pursue. It follows that a NGO could provide services or could sell goods with profit in more or less the same way that a commercial enterprise does but any net income which derives from its operations cannot be distributed to its members or be used to promote its members' private dealings. The third aspect is that NGOs may pursue their goals and objectives through their participation in alliances, federations or confederations of NGOs at national or transnational level.

This seems to allow the implementation of the right to the freedom of association to what would amount a second degree. In other words, this right is not to be exercised only by the direct recipients, namely the population residing in the territory of a state, but already established NGOs, which have a legal personality separate from that of their members, are also given the opportunity to exercise the freedom of association by setting up federations / confederations of NGOs. It should be noted that this has already happened in practice. NGOs (without necessarily sharing similar goals and activities) have formed federations, which fall into these three broad categories. The first category comprises federations on global scale, e.g. the World Association of Non-Governmental Organizations (WANGO), which was initiated in $2000,{ }^{11}$ and the International Federation of Human Rights, which has existed since 1922 and currently has 178 members. ${ }^{12}$ The second category comprises federations which have been set up according to the region in which they are active, e.g. Concord - the European NGO Confederation for Relief and Development, which was founded in 2003 and currently has 27 national associations. ${ }^{13}$

The third category comprises federations which have been set up according to the state where their activities are carried out. Examples of the latter category include the NGO Federation of Nepal (NFN), which was established in $1991,{ }^{14}$ the Bangladesh NGO Foundation, which was

11. See http://www.wango.org. Note that WANGO adopted in 2002 a Code of Ethics and Conduct for NGOs, available at http://www.wango.org/codeofethics.aspx.

12. See http://www.fidh.org. According to FIDH, there are four elements that allow it a play a unique role in realizing human rights worldwide: its legitimacy, experience, methods and credibility.

13. See http://www.concordeurope.org.

14. See http://www.ngofederation.org. Currently, 5,370 Nepalese NGOs are affiliated with NFN. 
created in 2004 to associate national NGOs in the process of achieving the Millennium Development Goals, ${ }^{15}$ and the Association of NGOs in Norway (Frivillighet Norge), an umbrella organization for the voluntary sector in Norway, which was founded in 2005 and currently consists of more than 280 members. ${ }^{16}$ It is interesting to note that associations of the third category participate in confederations of NGOs, which, in their turn, could come under the ambit of the first category and/or the second category. Thus, Frivillighet Norge is at the same time a member of CIVICUS (World Alliance for Citizen Participation) ${ }^{17}$ and a member of ENNA (European Network of National Civil Society Associations). ${ }^{18}$

\section{CONCLUSIONS}

As has been mentioned, in Greece the establishment and the operation of NGOs is made possible through 'loans' from other institutions, which are envisaged in the Civil Code. With only few exceptions, even the term 'NGO' is not met in the Greek legislation. Notwithstanding this reality, NGO have existed for many decades now and constitute one of the actors that participate actively in societal affairs. They expect that their voice will be heard because, as they claim, they represent society at large. Even though, as an actor, NGOs are imperfect entities in the sense that arguably they have not yet run a full cycle of life which would have endowed them with a certain degree of maturity and sophistication, there is everything to suggest that their role and their importance but also their value will increase in the times to come. For this reason alone, the argument will be made that the Greek Civil Code should be amended to introduce the legal vehicle of NGOs as an alternative way of exercising the right to the freedom of association. We believe that it is not necessary to amend the Constitution in order to introduce NGOs formally into the Greek

15. See http://www.ngofoundation.org.bd. Although it is not a private initiative, in the sense that it was set up under a government decision, it deserves to be mentioned.

16. See http://www.frivillighetnorge.no/no/English.

17. See www. civicus.org.

18. See http://www.enna-europe.org. 
legal order. ${ }^{19}$ If this proposal were turned into a legislative initiative, the instruments which have been adopted by the Council of Europe pertaining to NGOs (especially the 2007 Recommendation) offer not only inspiration but also the groundwork for drafting it.

19. Cf. G. Papadimitriou, "Legal Form of NGOs and the Constitution" in Annals of the First Pan-Hellenic Consultation, Contemporary Institutional Framework for Volun-

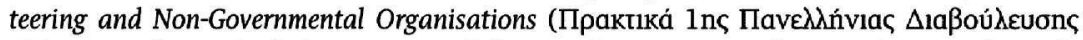

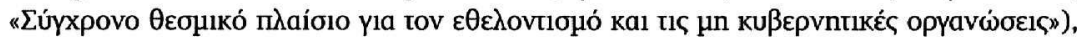
Athens, 2007, pp. 28-29, available at http://www.gpapadimitriou.gr/publications/ diafora/diaf37.html; and L. Papadopoulou, Constitution Fortification of Civil Society

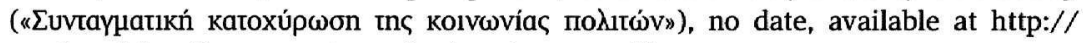
anatheorisi.parliament.gr/organizations/MKOLP.pdf. 